\title{
Performance of partial nitritation-anammox processes at mainstream conditions in an IFAS system
}

Alba Pedrouso, Jozef Trela, Angeles Val del Rio, Anuska Mosquera-Corral and Elzbieta Plaza

\section{Accepted Mansucript}

\section{How to cite:}

Pedrouso, A., Trela, J., Val del Rio, A., Mosquera-Corral, A., \& Plaza, E. (2019). Performance of partial nitritation-anammox processes at mainstream conditions in an IFAS system. Journal Of Environmental Management, 250, 109538. doi: 10.1016/j.jenvman.2019.109538

\section{Copyright information:}

(C) 2019 Elsevier Ltd. This manuscript version is made available under the CC-BY-NC-ND 4.0 license (http://creativecommons.org/licenses/by-nc-nd/4.0/) 


\title{
Performance of partial nitritation-anammox processes at mainstream conditions in an IFAS system
}

Doi: https://doi.org/10.1016/j.jenvman.2019.109538

\section{Alba Pedrouso ${ }^{\mathrm{a}}$, Jozef Trela $^{\mathrm{b}}$, Angeles Val del Rio ${ }^{\mathrm{a}}$, Anuska Mosquera-Corral ${ }^{\mathrm{a}}$ and Elzbieta Plaza ${ }^{\text {b }}$}

\author{
a Department of Chemical Engineering, School of Engineering, Universidade de Santiago de Compostela, \\ Rúa de Lope Gómez de Marzoa s/n, E-15782. Santiago de Compostela, Galicia, Spain. E-mail: \\ alba.pedrouso@usc.es,mangeles.val@usc.es, and anuska.mosquera@usc.es \\ ${ }^{\mathrm{b}}$ Department of Sustainable Development, Environmental Science and Engineering, Royal Institute of \\ Technology (KTH), Teknikringen 10B, SE-10044, Stockholm, Sweden. E-mail: trela@kth.se, \\ elap@kth.se \\ *Corresponding author: Alba Pedrouso, Email: alba.pedrouso@usc.es, Phone: +34 881816739
}

\begin{abstract}
:
The partial nitritation-anammox processes implementation in the main line of wastewater treatment plants would lead them closer to the energy autarky. With this purpose, an integrated fixed film activated sludge (IFAS) reactor was operated at pilot scale. Efficient nitrogen removal $(72 \pm 11 \%)$ was achieved for anaerobically pre-treated municipal wastewater at low temperature $\left(21-15^{\circ} \mathrm{C}\right)$, with a nitrogen removal rate of $37 \pm 3 \mathrm{~g} \mathrm{~N} /\left(\mathrm{m}^{3} \cdot \mathrm{d}\right)$ at $15^{\circ} \mathrm{C}$. The ammonium oxidizing bacteria were more abundant in the activated sludge, while anammox bacteria were primarily located in biofilm attached onto the carriers surface. Nitrite oxidizing bacteria (NOB) activity was similar between both fractions and its specific activity decreased more than that of other populations when the operating temperature was reduced. Furthermore, the IFAS operational strategy (aerobic/anoxic periods) allowed an efficient NOB activity suppression inside the reactor, which accounted only for the $10-20 \%$ of the maximum potential activity.
\end{abstract}

Keywords: anammox; autotrophic nitrogen removal; integrated fixed film activated sludge; mainstream; nitritation. 


\section{Introduction}

The long-term stability of the partial nitritation-anammox (PN/AMX) processes operating at mainstream conditions, characterized by low ammonium concentration $(<100 \mathrm{mg} \mathrm{N} / \mathrm{L})$ and low temperature $\left(<25^{\circ} \mathrm{C}\right)$, remains as a challenge. The main identified bottlenecks are the achievement of the stringent discharge limits, the effective suppression of nitrite oxidizing bacteria (NOB) growth and the effective anammox bacteria retention inside the reactor (Cao et al., 2017; Hoekstra et al., 2018). Different strategies were proposed to suppress the NOB activity (Agrawal et al., 2018; Cao et al., 2017; Ge et al., 2015). Among them, some authors suggest performing the PN/AMX processes in two reactors where each process is optimized separately (Dosta et al., 2015; Pérez et al., 2015). Compared to the one-stage option, the two-stage PN/AMX system requires more space for implantation, a more complex control system, higher capital costs and it was reported to presumably lead to higher greenhouse gases emissions (Lackner et al., 2014). Therefore, the hybrid biofilm-based technologies and their ability to decouple the solid retention time (SRT) of different populations arose as promising approaches to improve the process stability joining the advantages of both one-stage and two-stage configurations (Han et al., 2016; Veuillet et al., 2014).

Recently, hybrid systems like integrated fixed film activated sludge (IFAS) reactors where sludge is a mixture of suspended and biofilm biomass, have been explored to perform the PN/AMX processes simultaneously (Veuillet et al., 2014). The IFAS reactors have been found to be more flexible, efficient and resistant against both concentration and hydraulic shock loads than other activated sludge processes (Regmi et al., 2011). Due to mass transfer limitations, anammox bacteria preferentially grow in the biofilm while the ammonium oxidizing bacteria (AOB) and NOB are mainly developed as suspended biomass (Veuillet et al., 2014). Thus, IFAS reactor provides the opportunity to experience a more versatile operation and potentially obtain a selectively NOB washout, while anammox bacteria remain in the system. However, scarce information is available regarding the PN/AMX processes applied for the treatment of municipal wastewater at low temperatures in IFAS reactors (Table 1). For example, Yang et al. (2017) operated a plug-flow IFAS system, at $24-26^{\circ} \mathrm{C}$, treating aerobically pre-treated wastewater with a total nitrogen loading rate (NLR) of $125 \mathrm{mg} \mathrm{N} /(\mathrm{L} \cdot \mathrm{d})$. These authors achieved an effluent containing total nitrogen (TN) concentrations lower than $10 \mathrm{mg} \mathrm{N} / \mathrm{L}$ (commonly established discharge limit) by applying a strategy based on the residual ammonium 
concentration ( 3 - $5 \mathrm{mg} \mathrm{N} / \mathrm{L}$ ). Nevertheless, these authors stated that the long-term process stability is still an issue requiring the strict control of the airflow rate to maintain the microaerobic conditions ( 0.15 to $0.36 \mathrm{mg} \mathrm{O}_{2} / \mathrm{L}$ ) (Yang et al., 2017). Furthermore, the use of intermittent aeration was widely used. Malovanyy et al. (2015) optimized the intermittent aeration strategy (15 min ON/45 min OFF) obtaining a nitrogen removal efficiency (NRE) up to $70 \%$ for anaerobically pre-treated wastewater in a continuous IFAS system at $25{ }^{\circ} \mathrm{C}$. Trojanowicz et al. (2016) run a similar system at $17{ }^{\circ} \mathrm{C}$ but the obtained NRE was limited to $44 \%$, mainly due to the nitrate produced by the NOB activity, probably caused by the low operational temperature. Laureni et al. (2016) treated low loaded wastewater at $15{ }^{\circ} \mathrm{C}$ in a laboratory reactor achieving a NRE of $63 \%$. However, the applied microaerobic conditions to suppress the NOB activity limited the ammonium oxidation rate and therefore the nitrogen removal rate (NRR) was approximately of $23 \mathrm{~g} \mathrm{~N} /\left(\mathrm{m}^{3} \cdot \mathrm{d}\right)$.

Table 1. Comparison of PN/AMX reactors based on an IFAS system applied to treat municipal wastewater at mainstream conditions.

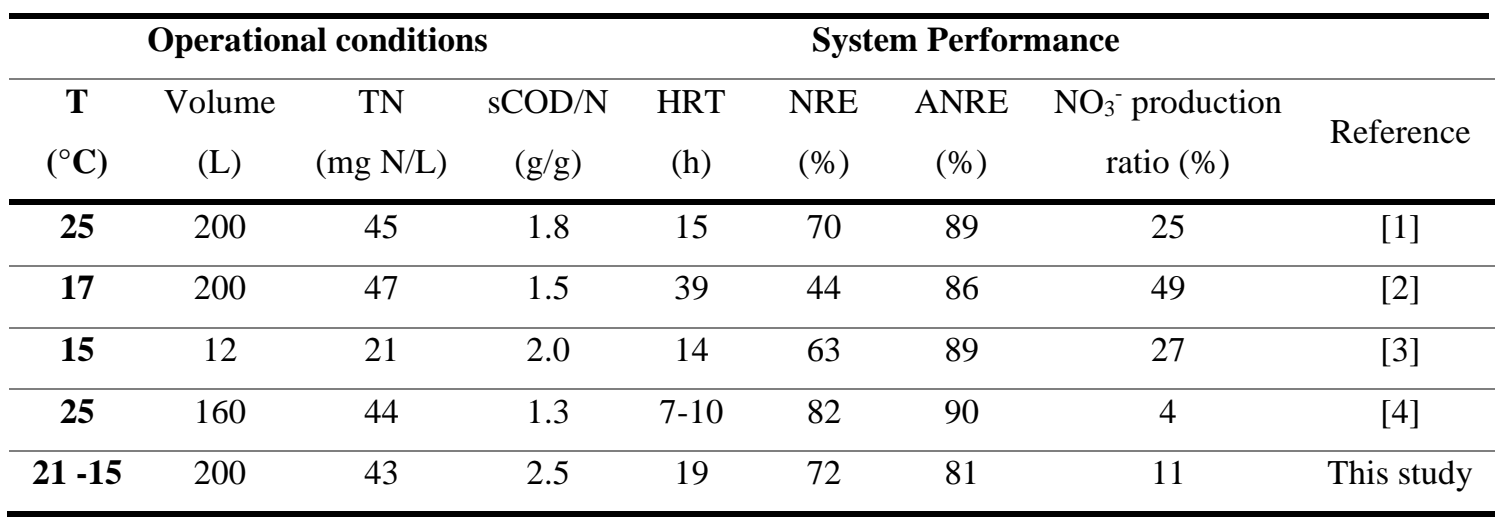

[1] Malovanyy et al. (2015); [2] Trojanowicz et al. (2016); [3] Laureni et al. (2016); [4] Yang et al. (2017); ANRE: ammonium nitrogen removal efficiency; HRT: hydraulic retention time; NRE: nitrogen removal efficiency;.sCOD/N: soluble chemical oxygen demand to nitrogen ratio; $\mathrm{T}$ : temperature; $\mathrm{TN}$ : total nitrogen.

Hence, the main objective of this study is to evaluate the performance and stability of the PN/AMX processes taking place in a pilot-scale IFAS system operated at mainstream conditions. As novelty, the reactor was operated at low temperatures $\left(21-15^{\circ} \mathrm{C}\right)$ with the added challenge of treating anaerobically pre-treated wastewater with a soluble chemical oxygen demand (sCOD) to ammonium nitrogen ratio of $2.5 \pm 0.3 \mathrm{~g}$ sCOD/g N. Furthermore, a detailed study of the microbial population segregation between suspended and biofilm fractions is presented to understand the reasons for the NOB activity limitation inside the reactor. 


\section{Material and Methods}

\subsection{IFAS pilot plant setup}

An IFAS pilot scale reactor with a working volume of $200 \mathrm{~L}$ was used. It was filled with AnoxKaldnes K1 biofilm carriers, 40\% volume, (see Figure S1 in Supplementary Material) characterized by an effective surface area of $500 \mathrm{~m}^{2} / \mathrm{m}^{3}$ carrier. The suspended sludge, leaving the unit, settled in a sedimentation tank (100 L) from which the concentrated sludge was recirculated back to the reactor at a recirculation ratio of $1(100 \%$ of the flow rate at which wastewater was fed to the system, $260 \mathrm{~L} / \mathrm{d})$. The IFAS reactor was operated as a continuous stirred-tank with intermittent aeration (alternation between aerobic and anoxic periods). The dissolved oxygen (DO) concentration inside the reactor, during the aerated phases, was fixed at a set point of $1.5 \mathrm{mg} \mathrm{O}_{2} / \mathrm{L}$, although this set point was more difficult to maintain as the temperature dropped. This set point was regulated by a PID (proportional-integral-derivative) controller (Cerlic AB, Sweden), which adjusted the airflow rate. The $\mathrm{pH}$ was not controlled and was of $6.95 \pm 0.20$. The process performance was monitored by online measurements of temperature, DO concentration, $\mathrm{pH}$, suspended solids (SS) concentration, oxidation-reduction potential (ORP), ammonium nitrogen and nitrate nitrogen concentrations inside the reactor. Additionally, the reactor was also equipped with conductivity sensors of both influent and mixed liquor. All data from the on-line sensors were recorded and collected in a data acquisition system.

\subsection{IFAS operational conditions}

The IFAS reactor has been operated for years before the beginning of the present research study. During that period, it treated low strength nitrogen streams at temperatures of 21 $25^{\circ} \mathrm{C}$ (Malovanyy et al., 2015). The reactor was operated for 100 days divided into three different stages as the temperature was step-wise decreased from $21{ }^{\circ} \mathrm{C}$ (Stage I, days 0 33 ) to $18{ }^{\circ} \mathrm{C}$ (Stage II, days 34 - 79) and finally to $15^{\circ} \mathrm{C}$ in Stage III (days 80 - 100). The temperature was continuously monitored and regulated by both immerse cooler and heater connected to a thermostat (Julabo AB, Sweden). Moreover, the intermittent aeration pattern was changed from $15 \mathrm{~min}$ ON/45 min OFF periods to $20 \mathrm{~min}$ ON/40 $\mathrm{min}$ OFF from day 38 onwards.

The IFAS reactor operated at the Hammarby Sjöstadsverk research facility (Stockholm, Sweden). This facility is located directly on top of the Henriksdal WWTP and provided with a direct discharge point for municipal wastewater, which was used as feeding. The 
municipal wastewater was pre-treated in a primary settler and an upflow anaerobic sludge blanket (UASB) reactor $\left(6.3 \mathrm{~m}^{3}\right)$ operated at $20{ }^{\circ} \mathrm{C}$ to remove the organic matter (Malovanyy et al., 2015). Then, a fraction of the UASB effluent was filtrated through a $20 \mu \mathrm{m}$ pore size filter and stored in an equalization tank $\left(2 \mathrm{~m}^{3}\right)$ to reduce the incoming solid concentration and to mitigate the wastewater composition fluctuations. Afterwards, it was continuously fed to the IFAS unit with the following composition: $38-48 \mathrm{mg}$ $\mathrm{NH}_{4}{ }^{+}-\mathrm{N} / \mathrm{L}, 110$ - $138 \mathrm{mg}$ soluble COD/L, 235 - $283 \mathrm{mg} \mathrm{CaCO} / \mathrm{L}, 5-22 \mathrm{mg} \mathrm{VSS} / \mathrm{L}$ and average $\mathrm{pH}$ values of $7.5 \pm 0.1$.

The hydraulic retention time (HRT) in the IFAS reactor was maintained constant at $19 \mathrm{~h}$ resulting in an average NLR of $56 \pm 3 \mathrm{~g} \mathrm{~N} /\left(\mathrm{m}^{3} \cdot \mathrm{d}\right)$, varying only due to the nitrogen concentration fluctuations.

\subsection{Analytical methods}

To monitor the pilot plant performance and to check and calibrate the online sensors, both influent and effluent were periodically sampled and filtered using $0.45 \mu \mathrm{m}$ pore size filters. Then, the concentrations of chemical oxygen demand (COD), total nitrogen (TN), ammonium, nitrite, nitrate and alkalinity were measured spectrophotometrically with $\mathrm{Dr}$ Lange test kits (Hach Lange, Germany) in a Photolab ${ }^{\circledR} 6600$ UV-Vis. Potassium and chlorine ion concentrations were also spectrophotometrically determined (with WTW Spectroquant in a Dr Lange ION 500) to calibrate the ammonium and nitrate online sensors, respectively. Concentrations of total suspended solids (TSS) and volatile suspended solids (VSS) were determined according to the Standards Methods (American Public Health Association et al., 2017) in the influent, effluent and the mixed liquor from the bioreactor. The biomass concentration, TSS and VSS, corresponding to the biofilm was determined after the mechanical detachment of the biomass (Figure S1 in Supplementary Material) from a randomly selected known number of carriers.

\subsection{Microbial activity batch tests}

To follow up the microbial process performance inside the reactor, specific activity (SA) tests were carried out on both biofilm and suspended biomass samples taken out from the IFAS reactor. The maximum specific anammox activity ( $\mathrm{SA}_{\mathrm{AMx}}$ ), in $\mathrm{mg} \mathrm{N}_{2}-\mathrm{N} /(\mathrm{g}$ VSS $\cdot \mathrm{d}$ ), was determined according to Dapena-Mora et al. (2007). A modification of the SAA method was also used to determine the activity of heterotrophic denitrifying (SAHD) bacteria adding as substrate nitrate (50 mg N/L) and acetate (100 mg COD/L). Activities 
of aerobic heterotrophs $\left(\mathrm{SA}_{\mathrm{AerH}}\right), \mathrm{AOB}\left(\mathrm{SA}_{\mathrm{AOB}}\right)$ and $\mathrm{NOB}\left(\mathrm{SA}_{\mathrm{NOB}}\right)$ were determined according to the method described by Surmacz-Gorska et al. (1996). All these batch assays were performed at the corresponding IFAS reactor operational temperature at the moment of the biomass collection. Moreover, SAA was also determined at $30{ }^{\circ} \mathrm{C}$, considered as reference temperature for anammox bacteria.

\subsection{Identification of microbial populations}

The main active bacterial populations present in the suspended sludge and biofilm biomass samples were identified in samples collected from the IFAS reactor on day 75 (Stage II). The fluorescence in situ hybridization (FISH) molecular technique was applied following the protocol described by Amann et al. (1990). Biomass was manually detached from the surface of $\mathrm{K} 1$ carriers to avoid bacterial deactivation. The specific

oligonucleotide probes used (Table S1 in Supplementary Material) were 5'-labelled with the fluorochromes FITC (fluorescei-5-isocyanate) or Cy3 (Carbocyanine 3). Details of the oligonucleotide probes are available at probeBase (Greuter et al., 2016). DAPI (4,6diamindino-2-phenylindole) was used as universal dye for all DNA. Fluorescence signals were recorded with an acquisition system (Coolsnap, Roper Scientfic Photometrics) coupled to an Axioskop 2 Plus epifluorescence microscope (Zeiss, Germany). The relative abundances of $\mathrm{AOB}, \mathrm{NOB}$ and anammox bacteria were estimated by semiquantitative counting of the ratio between their specific microbial populations biovolume and the total bacterial biovolume using the DAIME software (Daims et al., 2006).

\subsection{Calculations}

Statistical differences between the results obtained in the three operational stages were tested by one-factor analysis of variance (ANOVA) using the statistical software $\mathrm{R}$ version 3.5.2 (The R Foundation Statistical Computing). Prior to ANOVA, variance homogeneity was confirmed by Levene's test and normal distribution by the Shaphiro's test. Then, if the ANOVA confirmed the difference between mean values, a post hoc analysis (Tukey's HSD) was applied to determine between which values the difference was significant, considering a level of significance of 0.05 . If data variance homogeneity and/or normal distribution was not met, the non-parametric Kruskal-Wallis analysis was applied and afterwards the Wilcoxon post hoc one. 


\section{Results and discussion}

\subsection{Nitrogen removal in the IFAS PN/AMX reactor at decreasing temperatures}

The operational strategy imposed to the IFAS PN/AMX pilot plant, continuous feeding and intermittent aeration cycles, was defined to promote the performance of anoxic processes and exploit the lag phase of NOB bacteria activity after oxygen starvation. The NOB suppression is crucial during the operation at the low temperatures to be tested of 21,18 and $15{ }^{\circ} \mathrm{C}$.

Initially (Stage I), the daily average DO concentration was of $0.45 \mathrm{mg} \mathrm{O}_{2} / \mathrm{L}$ (Table 2) and the PN/AMX processes performance was stable. The concentration of TN in the effluent at the end of this stage was lower than $10 \mathrm{mg} \mathrm{N} / \mathrm{L}$ corresponding to $4.0 \pm 1.5 \mathrm{mg} \mathrm{NH}_{4}{ }^{+}-$ $\mathrm{N} / \mathrm{L}, 3.0 \pm 2.2 \mathrm{mg} \mathrm{NO}_{3}{ }^{-} \mathrm{N} / \mathrm{L}$ and less than $0.2 \mathrm{mg} \mathrm{NO}_{2}{ }^{-}-\mathrm{N} / \mathrm{L}$ (Figure 1.A). Ammonium nitrogen removal efficiency (ANRE) and NRE reached values of $80 \pm 13 \%$ and $73 \pm$ $12 \%$, respectively (Figure 1.B and Table 2). The observed nitrate production ratio was only $9 \pm 5 \%$, which indicated a negligible NOB activity inside the reactor (Table 2). Then, the NRE increased reaching average values of $85 \%$ in the last 10 days of this period.

Table 2. Average values for the reactor performance at decreasing temperatures.

\begin{tabular}{|c|c|c|c|}
\hline & S-I $\left(21^{\circ} \mathrm{C}\right)$ & $\mathrm{S}-\mathrm{II}\left(18^{\circ} \mathrm{C}\right)$ & $\mathrm{S}-\mathrm{III}\left(15^{\circ} \mathrm{C}\right)$ \\
\hline Phase length (days) & $0-33$ & $34-79$ & $80-100$ \\
\hline Daily DO (mg/L) & $0.45 \pm 0.05$ & $0.58 \pm 0.19$ & $0.64 \pm 0.07$ \\
\hline pH & $7.05 \pm 0.04$ & $6.83 \pm 0.13$ & $7.09 \pm 0.23$ \\
\hline $\operatorname{NRR}\left(\mathrm{g} \mathrm{N} /\left(\mathbf{m}^{3} \cdot \mathbf{d}\right)\right)$ & $40.04 \pm 5.05$ & $42.47 \pm 7.80$ & $37.35 \pm 3.32$ \\
\hline NRE (\%) & $72.5 \pm 12.7$ & $74.1 \pm 11.4$ & $65.8 \pm 4.9$ \\
\hline ANRE (\%) & $80.0 \pm 13.4$ & $84.4 \pm 11.4$ & $77.5 \pm 10.5$ \\
\hline$\left.\left(\mathrm{NO}_{3}\right)^{-}\right)_{\text {produced }} /\left(\mathrm{NH}_{4}{ }^{+}\right)_{\text {consumed }}(\%)$ & $9.4 \pm 5.7$ & $11.3 \pm 9.1$ & $12.5 \pm 9.1$ \\
\hline $\mathrm{NO}_{2}^{-}-\mathrm{N}_{\mathrm{e}}(\mathrm{mg} \mathrm{N} / \mathrm{L})$ & $0.10 \pm 0.07$ & $0.29 \pm 0.13$ & $0.54 \pm 0.23$ \\
\hline $\mathrm{TN}_{\mathrm{e}}(\mathrm{mg} \mathrm{N} / \mathrm{L})$ & $10.9 \pm 5.6$ & $10.8 \pm 5.3$ & $15.0 \pm 2.3$ \\
\hline $\mathrm{COD}_{\mathrm{e}}(\mathrm{mg} / \mathrm{L})$ & $32.8 \pm 0.7$ & $44.5 \pm 3.4$ & $46.0 \pm 4.9$ \\
\hline $\operatorname{VSS}_{\mathbf{r}}(\mathrm{g} / \mathrm{L})$ & $1.03 \pm 0.12$ & $1.05 \pm 0.15$ & $1.03 \pm 0.09$ \\
\hline
\end{tabular}

ANRE: ammonium nitrogen removal efficiency; COD: chemical oxygen demand; NRE: nitrogen removal efficiency; NRR: nitrogen removal rate; TN: total nitrogen; VSS: volatile suspended solids. Sub-indexes "e" and " $r$ " refer to concentration measured in the effluent and inside the reactors, respectively. 
On day 34 the temperature was decreased to $18{ }^{\circ} \mathrm{C}$ (Stage II) resulting in an immediate decrease of the NRE due to ammonium accumulation up to $13 \mathrm{mg} \mathrm{NH}_{4}{ }^{+} \mathrm{N} / \mathrm{L}$, whereas nitrate concentration remained similar to the values at the end of Stage $\mathrm{I}\left(<1 \mathrm{mg} \mathrm{NO} \mathrm{N}^{-}-\right.$ N/L) (Figure 1A). The relatively short oxygen supply periods and the low applied DO concentration in these periods $\left(1.5 \mathrm{mg} \mathrm{O}_{2} / \mathrm{L}\right)$, resulted in daily average DO concentrations of $0.49 \mathrm{mg} \mathrm{O} / \mathrm{L}$. Thus, on day 39 the intermittent aeration length was increased from 15 min to $20 \mathrm{~min}$ and the anoxic phase reduced from 45 to $40 \mathrm{~min}$, to diminish the $\mathrm{AOB}$ activity limitations. Then, the average daily DO concentration increased to $0.58 \mathrm{mg} \mathrm{O} / \mathrm{L}$ (Table 2). Consequently, the ANRE increased and the NRE stabilized at average values of $74 \%$. Thus, the differences of the respective NRE and ANRE values corresponding to Stage I $\left(21^{\circ} \mathrm{C}\right)$ and Stage II $\left(18^{\circ} \mathrm{C}\right)$ were statistically insignificant according to the results from ANOVA $(\mathrm{p}=0.925)$ and Kruskal-Wallis $(\mathrm{p}=0.485)$ analysis, respectively. Thus, no effect can be attributed to the temperature reduction, from 21 to $18{ }^{\circ} \mathrm{C}$, over the performance of the PN/AMX processes.

A)

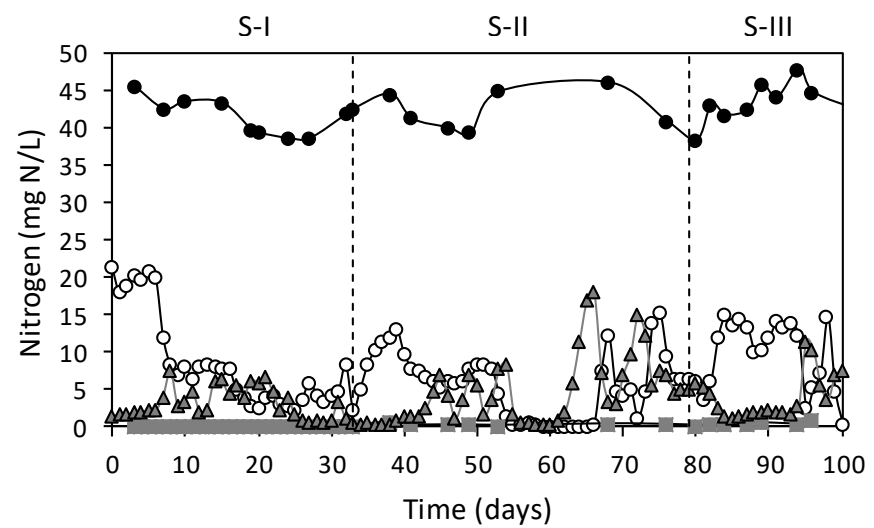

B)

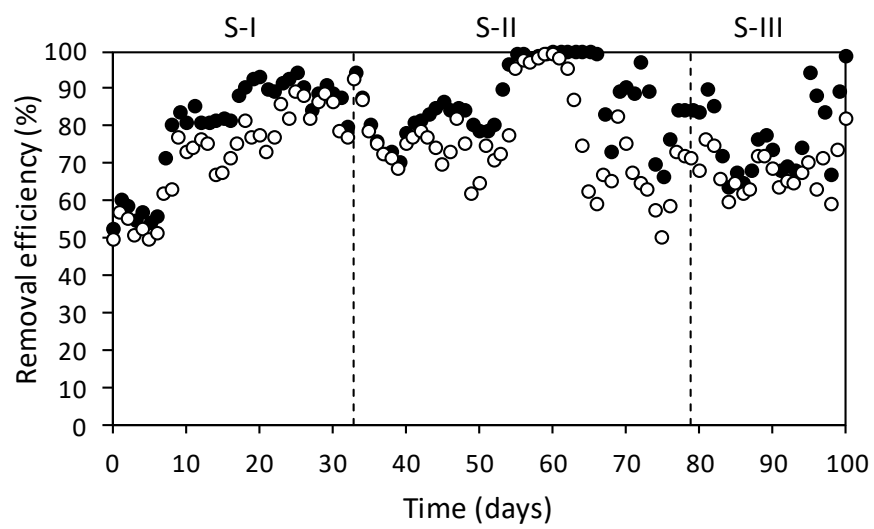

Figure 1. IFAS reactor performance: A) Evolution of the ammonium concentration in the influent $(\bullet)$, and effluent concentrations of ammonium ( $($ ), nitrite ( $(-)$ and nitrate $(\Delta)$ in $\mathrm{mg} \mathrm{N} / \mathrm{L}$. B) Evolution of ammonium nitrogen removal efficiency (ANRE, $\bullet$ ) and nitrogen removal efficiency (NRE, ○) in \%. 
Finally, the temperature was further diminished to $15^{\circ} \mathrm{C}$ (Stage III). NRR of $43 \mathrm{~g} \mathrm{~N} /\left(\mathrm{m}^{3}\right.$ d) was reached, with the maximum NRE of $75.6 \%$ and average values of $65.8 \pm 4.9 \%$ (Figure 1.B and Table 2). At $15{ }^{\circ} \mathrm{C}$ both ANRE and NRE were reduced regarding the previous Stages (Kruskal-Wallis $\mathrm{p}=0.044$ and $\mathrm{p}=0.0006$, respectively). NRE obtained in this last Stage III were significantly different from those measured in the previous Stages (with a $99.92 \%$ of confidence). Whereas the post-hoc Wilcoxon test pointed out that the ANRE from Stages II and III were significant different $(\mathrm{p}=0.040)$, while no significant differences were found by comparing Stages I and III $(\mathrm{p}=0.074)$.

Nitrate production ratio slightly increased from $9.4 \%$ in Stage I to $12.5 \%$ in Stage III (Kruskal-Wallis, $\mathrm{p}=0.036$ ). Furthermore, significant differences were found between the operation at $18{ }^{\circ} \mathrm{C}$ and $15^{\circ} \mathrm{C}$ (Wilcoxon, $\mathrm{p}=0.027$ ). Nitrate concentrations in the effluent fluctuated, reaching sporadic nitrate production rates as high as $35 \%$. These results indicated the existence of NOB activity in the biomass, as well as its activity suppression inside the reactor due to the imposed operational strategy which lead to minimum values of $5 \%$.

During the whole operational period, the nitrite concentration in the effluent was almost negligible with a maximum value of $0.89 \mathrm{mg} \mathrm{NO}_{2}^{-}-\mathrm{N} / \mathrm{L}$ (Figure 1.A and Table 2), whereas ammonium was still present, indicating that the nitritation process was limited. Despite the nitrite accumulation was scarce, a certain upward trend of nitrite concentration was observed with the temperature decrease. Thus, at low temperature, AOB activity was presumably favoured over the nitrite consuming bacteria activities (either anammox bacteria or NOB). Although the nitrate produced to ammonium consumed ratio was, in Stages I and II, close to the stoichiometric value of $0.11 \mathrm{~g} \mathrm{NO}_{3}{ }^{-} \mathrm{N} / \mathrm{g} \mathrm{NH}{ }_{4}{ }^{+}-\mathrm{N}$, according to the PN/AMX reactions (Cao et al., 2017), in Stage III at $15^{\circ} \mathrm{C}$ it was frequently higher, diminishing the NRE (Table 2).

Besides nitrogen, an average COD removal rate of $82 \pm 22 \mathrm{~g} \mathrm{COD} /\left(\mathrm{m}^{3} \cdot \mathrm{d}\right)$ was achieved, which could be via both aerobic and/or anoxic routes. Thus, the COD concentration in the effluent remained in average as $43 \pm 6 \mathrm{mg} \mathrm{sCOD} / \mathrm{L}$, for the whole operational period, lower than the discharge limit in the European Union of $125 \mathrm{mg}$ COD/L. The sCOD/N ratio in the influent to the IFAS reactor was relatively high $(2.5 \pm 0.3 \mathrm{~g} \mathrm{sCOD} / \mathrm{N})$ and close to the limit values recommended to guarantee the correct performance of the autotrophic processes (Agrawal et al., 2018; Cao et al., 2017), and avoid the development of the heterotrophic denitrifying bacteria which might outcompete the anammox bacteria. 
However, the ratio corresponding to the COD and $\mathrm{N}$ removed obtained was of $2.1 \pm 0.5$ g COD/g N, considerably lower than that normally needed for heterotrophic denitrification of $5 \mathrm{~g} \mathrm{COD} / \mathrm{N}$ (Burton et al., 2014). Considering that all the COD consumed was used for the heterotrophic denitrification (most negative case, because it can be consumed also by aerobic heterotrophs), a maximum of $35 \%$ of the total NRR could be attributed to this process, consequently, the PN/AMX processes should be considered as the main route for the achieved nitrogen removal. Another advantage of the hybrid reactors is that usually tolerate higher COD concentration than other one-stage PN/AMX systems. Despite this, the further optimization of the UASB reactor, with current limited COD removal efficiency of $50 \%$, would help to improve the PN/AMX system performance.

\subsection{Removal rate and effluent quality of the PN/AMX systems at mainstream conditions}

In the present study, stable NRE (72 $\pm 11 \%$ in average) took place while average NRR of $39 \pm 6 \mathrm{~g} \mathrm{~N} /\left(\mathrm{m}^{3} \cdot \mathrm{d}\right)$ were achieved in the PN/AMX IFAS pilot plant treating anaerobically pre-treated municipal wastewater at low temperature $\left(21-15^{\circ} \mathrm{C}\right)$ (Figure 1). Reached NRR were in the range of those reported for other systems and/or at higher temperatures. As an example, Laureni et al. (2016) operated a SBR lab-scale IFAS system under microaerobic conditions and reached a NRR of $23 \mathrm{~g} \mathrm{~N} /\left(\mathrm{m}^{3} \cdot \mathrm{d}\right)($ Table 1$)$. They hypothesized that the SBR cycle should be optimized by decreasing the HRT to increase the achieved NRR. At pilot scale, Pedrouso et al. (2018) also obtained comparable NRR $\left(33 \mathrm{~g} \mathrm{~N} /\left(\mathrm{m}^{3} \cdot \mathrm{d}\right)\right)$ treating primary settled municipal wastewater in a granular-biomass SBR at uncontrolled temperature ranging from 12 to $18{ }^{\circ} \mathrm{C}$. Han et al. (2016) got higher NRR of $60 \mathrm{~g} \mathrm{~N} /\left(\mathrm{m}^{3} \cdot \mathrm{d}\right)$, but the operational temperature was also considerably higher (19 - 31 $\left.{ }^{\circ} \mathrm{C}\right)$.

Specifically at $15^{\circ} \mathrm{C}$, a relatively high NRE was achieved in the present study $(65.8 \pm 4.9$ $\%$ at $15^{\circ} \mathrm{C}$ ), but further optimization of the reactor operation is required to meet the discharge limits as the TN concentration in the effluent was $12 \pm 5 \mathrm{mg} \mathrm{N} / \mathrm{L}(>10 \mathrm{mg}$ N/L). The low effluent quality was already pointed out as one of the drawbacks of the continuously fed PN/AMX systems by Hoekstra et al. (2018) who operated a 4-m ${ }^{3}$ complete mixed reactor where NRR as high as $97 \mathrm{~g} \mathrm{~N} /\left(\mathrm{m}^{3} \cdot \mathrm{d}\right)$ at $13.4 \pm 1.1{ }^{\circ} \mathrm{C}$ were reached. In this sense, the plug flow reactors (Lotti et al., 2015; Yang et al., 2017) or SBRs (Laureni et al., 2016; Pedrouso et al., 2018) are presumably more suitable for 
effluent quality optimization than the continuous complete mixed ones. Actually, it was demonstrated that using a residual ammonium concentration ( $2-5 \mathrm{mg} \mathrm{N} / \mathrm{L})$ as set point either to terminate the reaction (Laureni et al., 2016) or to adjust the airflow rate (Yang et al., 2017) or the HRT (Malovanyy et al., 2015), higher NRE are achieved. Indeed, Yang et al. (2017) obtained NRE of $82 \%$ at temperatures of $24-26^{\circ} \mathrm{C}$ (Table 1), in a system where also the denitrification process took place since the nitrate concentration in the effluent was lower than that expected considering the PN/AMX processes. In this way, the presence of COD contributed to the effluent polishing improving the final effluent quality.

\subsection{Intermittent aerobic/anoxic cycle characterization}

Although the reactor was fed in continuous mode, the alternating imposed aerobic/anoxic conditions produced the evolution of the different operational parameters monitored throughout each operational cycle. To evaluate the performance of the IFAS reactor in the three periods operated at 21,18 and $15{ }^{\circ} \mathrm{C}, 3$ operational cycles were monitored on days 20, 74 and 94, respectively. This behaviour is depicted in Figure 2. The biofilm biomass present inside the reactor was expected to be active in both, aerobic and anoxic periods, since the gradient of DO concentration created anoxic environments in the inner zones of the biofilm. The maximum penetration depth of the DO in the biofilm depended on the DO concentration in the media and of course was zero during the anoxic periods. In these conditions, ammonium was consumed in the aerobic (via AOB and anammox activities) and anoxic (via anammox activity) periods. However, due to the continuous feeding, the ammonium concentration decreased during the aeration periods and increased in the anoxic ones. Ammonium consumption by AOB and anammox bacteria was counterbalanced by the ammonium continuously fed to the system softening the concentration variations. Nitrate was produced in the aerobic periods (via NOB and anammox activities) and consumed (via heterotrophic denitrification) and produced (via anammox) in the anoxic ones. This concentration decrease occurred due to both the presence of heterotrophic denitrification activity and a dilution effect caused by the continuous feeding (as influent did not contain nitrate). The $\mathrm{pH}$ values also varied with the aeration pattern decreasing during the aerated phases due to the occurrence of the nitritation process and increasing in the anoxic phases due to the denitrification activity and, mainly, the effect of new influent coming to the system. 
A)

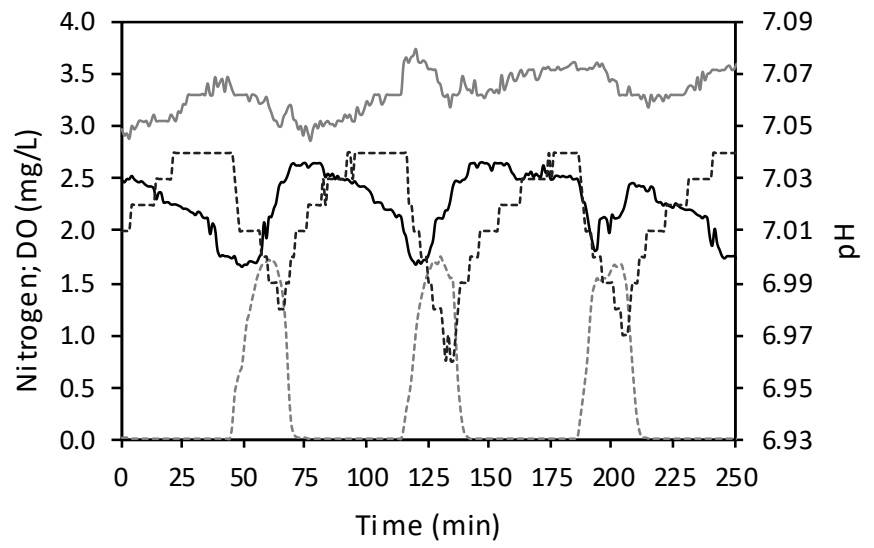

B)

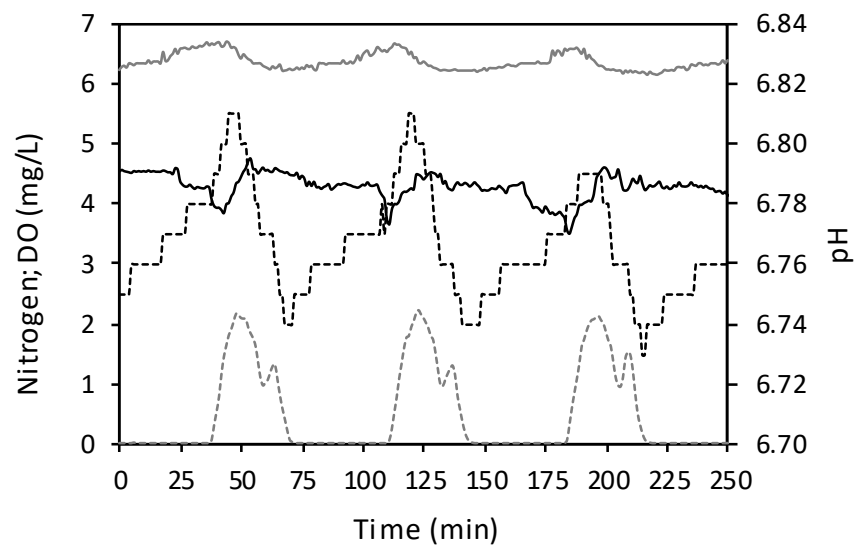

C)

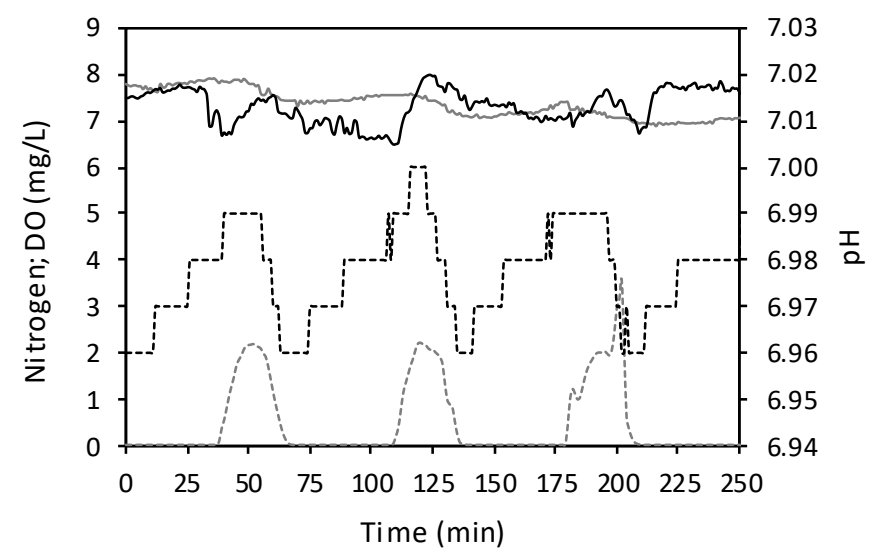

Figure 2. Evolution of $\mathrm{pH}(--)$ and concentrations of DO (--), ammonium (-) and nitrate (-) monitored during 3 representative aeration/anoxic cycles with 15 min ON and 45 min OFF in A) Stage I (Day 20); and with 20 min ON and 40 min OFF in B) Stage II (Day 74) and C) Stage III (Day 94).

The concentration profiles from Figure 2 together with the known amount of nitrogen fed, allowed estimating the consumption and production rates for ammonium and nitrate in the aerated and anoxic phases (Table 3). Due to the complexity and occurrence of multiple processes in the IFAS system in aerobic and anoxic phases (previously described), it was 
no possible to know the specific rate of each microbial group. For this purpose, it was useful the analysis of specific activities by batch tests, described in the next sections.

Table 3. Maximum observed conversion rates during the operational cycles at different temperatures.

\begin{tabular}{l|lll}
\hline & $\begin{array}{l}\mathbf{2 1}^{\circ} \mathbf{C} \\
\text { day }\end{array}$ & $\begin{array}{l}\mathbf{1 8}^{\circ} \mathbf{C} \\
\text { day } \mathbf{7 4}\end{array}$ & $\begin{array}{l}\mathbf{1 5}^{\circ} \mathbf{C} \\
\text { day } 94\end{array}$ \\
\hline $\mathrm{NH}_{4}{ }^{+}-\mathrm{N}$ consumed in aerated phase $\left(\mathrm{g} \mathrm{N} /\left(\mathrm{m}^{3} \cdot \mathrm{d}\right)\right)$ & 59 & 60 & 70 \\
$\mathrm{NH}_{4}{ }^{+}-\mathrm{N}$ consumed in anoxic phase $\left(\mathrm{g} \mathrm{N} /\left(\mathrm{m}^{3} \cdot \mathrm{d}\right)\right)$ & 33 & 32 & 44 \\
$\mathrm{NO}_{3}{ }^{-}-\mathrm{N}$ produced in aerated phase $\left(\mathrm{g} \mathrm{N} /\left(\mathrm{m}^{3} \cdot \mathrm{d}\right)\right)$ & 26 & 25 & 30 \\
$\mathrm{NO}_{3}{ }^{-}-\mathrm{N}$ consumed in anoxic phase $\left(\mathrm{g} \mathrm{N} /\left(\mathrm{m}^{3} \cdot \mathrm{d}\right)\right)$ & 13 & 15 & 8 \\
$\mathrm{NLR}\left(\mathrm{g} \mathrm{N} /\left(\mathrm{m}^{3} \cdot \mathrm{d}\right)\right.$ & 51 & 53 & 58 \\
$\mathrm{NRR}\left(\mathrm{g} \mathrm{N} /\left(\mathrm{m}^{3} \cdot \mathrm{d}\right)\right)$ & 44 & 39 & 40 \\
\hline
\end{tabular}

*NLR: nitrogen loading rate; NRR: nitrogen removal rate.

Despite the higher DO solubility at $18{ }^{\circ} \mathrm{C}$ compared to that at $21^{\circ} \mathrm{C}$, the nitrate production rate in the aerated phase (associated to the NOB activity) remained unaltered and the temperature did not negatively affect the rest of the observed nitrogen conversion rates (Table 3). The achieved repression of NOB activity correlated with the appearance of a lag phase in the nitrate production profile since it started approximately 10 minutes after the increase of the DO concentration (Figure 2).

At the lowest temperature tested of $15^{\circ} \mathrm{C}$, ammonium consumption and nitrate production rates significantly increased (Table 3), probably due to the higher DO availability. At 15 ${ }^{\circ} \mathrm{C}$, the oxygen solubility increased and complicated the control DO concentration leading to DO concentrations higher than $1.5 \mathrm{mg} \mathrm{O}_{2} / \mathrm{L}$, the fixed set point, for more than $10 \mathrm{~min}$. Even so, DO concentrations as high as $3 \mathrm{mg} \mathrm{O}_{2} / \mathrm{L}$ were reached. Then it remained close to zero for only 30 of the $40 \mathrm{~min}$ of the anoxic phase length resulting in average daily concentrations of $0.64 \pm 0.07 \mathrm{mg} \mathrm{O}_{2} / \mathrm{L}$, higher than in previous stages (Table 2). Once temperature decreased from 21 to $15^{\circ} \mathrm{C}$, ammonium oxidation increased in the aerated phase together with its removal in the anoxic phase (Table 3). This increase of ammonium removal was associated with the larger amount of nitrite available for the anammox bacteria. Furthermore, at the beginning of the anoxic phase, some aerobic transformation might occur since DO concentration decreased more slowly until reaching the required anoxic conditions. Considering that the ammonium conversion increased at decreasing temperatures, it can be stated that the nitrate production was the limiting step to improve the NRE in the system.

\subsection{Maximum specific microbial activities}


In the IFAS reactor, as it is a hybrid system, suspended and biofilm biomass coexisted. Both suspended solids concentration (approximately $1 \mathrm{~g} \mathrm{VSS} / \mathrm{L}$, Table 2) and biofilm biomass concentrations $\left(18 \mathrm{~g} \mathrm{VSS} / \mathrm{m}^{2}\right.$ ) remained practically constant during the reactor operation. Furthermore, the major part of the biomass (78\% of total biomass measured as VSS) grew attached to the carrier surface.

The contribution of biofilm and suspended biomass fractions to the different specific microbial activities was evaluated by batch activity tests. As expected, as the temperature decreased, the specific activities of the different microbial groups decreased (Figure 3), therefore the potential nitrogen removal capacity in the reactor diminished.

A)

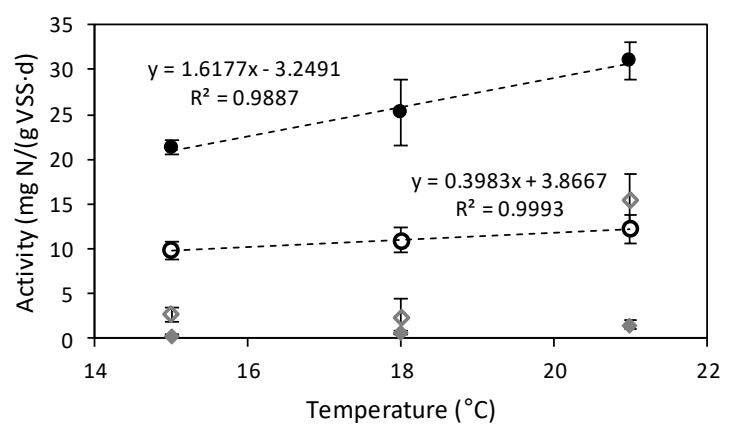

B)

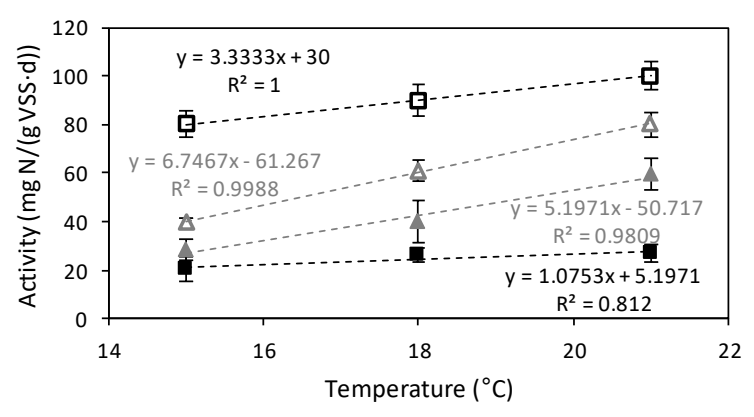

Figure 3. Evolution of the specific activities (SA) of the biomass from the IFAS reactor operated at decreasing temperatures. A) Specific anammox activity $\left(\mathrm{SA}_{\mathrm{AMX}}\right)$ of the biofilm $(\bullet)$ and suspended biomass $(\circ)$, specific denitrifying activity ( $\mathrm{SA}_{\mathrm{HDN}}$ ) of the biofilm ( $\bullet$ ) and suspended biomass $(\diamond)$. B) Nitrifying activities: AOB activity ( $\mathrm{SA}_{\mathrm{AOB}}$ ) of the biofilm ( $\left(\right.$ ) and suspended biomass ( $\square$ ), NOB activity ( $\mathrm{SA}_{\mathrm{NOB}}$ ) of the biofilm $(\Delta)$ and suspended biomass $(\triangle)$. All the activities are expressed as $\mathrm{mg} N /(\mathrm{g}$ VSS·d) and are average values in triplicate.

Results from SA tests indicated that biofilm biomass was mostly enriched in anammox bacteria. The $\mathrm{SA}_{\mathrm{AmX}}$ in the biofilm was at least twice as high as the one measured in the suspended sludge for the three tested temperatures (Figure 3.A). This difference slightly diminished with the temperature decrease, indicating that the suspended biomass was less affected by this change. In fact, the slope of the regression line fitting the measured $\mathrm{SA}_{\mathrm{AMX}}$ was 4 four times smaller than that corresponding to the biofilm biomass experiments (Figure 3.A). Moreover, the biofilm SAAMx value measured at $30{ }^{\circ} \mathrm{C}$, considered as the reference temperature, was of $83 \pm 3 \mathrm{mg} \mathrm{N}-\mathrm{N} /(\mathrm{g} \mathrm{VSS} \cdot \mathrm{d}$ ) in Stage I, and of $61 \pm 8 \mathrm{mg} \mathrm{N}$-N/(g VSS·d) in Stages II and III. This almost constant reference $\mathrm{SA}_{\mathrm{AMX}}$ indicates that the differences in the $\mathrm{SA}_{\mathrm{AMX}}$ values between Stages should be attributed to the temperature changes. The $\mathrm{SA}_{\mathrm{HD}}$ occurred preferentially in the suspended biomass fraction and it was less than $10 \%$ of the $\mathrm{SA}_{\mathrm{AMX}}$, except for the period 
at $21{ }^{\circ} \mathrm{C}$ (Figure 3.A). Thus, it can be stated that nitrogen removal in the IFAS reactor was mostly due to SAAmX.

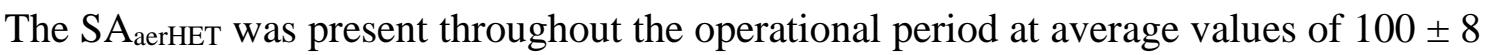
$\mathrm{mg} \mathrm{O} /(\mathrm{g} \mathrm{VSS} \cdot \mathrm{d})$ and $20 \pm 3 \mathrm{mg} \mathrm{O} /(\mathrm{g} \mathrm{VSS} \cdot \mathrm{d})$ for the suspended and biofilm biomass, respectively. Moreover, the $\mathrm{SA}_{\mathrm{AOB}}$ and $\mathrm{SA}_{\mathrm{NOB}}$ in suspended biomass were also higher than in the biofilm. In the suspended sludge, the $\mathrm{SA}_{\mathrm{AOB}}$ was higher than $\mathrm{SA}_{\mathrm{NOB}}$ whereas the latter was higher in the biofilm biomass (Figure 3.B). In both biomass fractions, the $\mathrm{SA}_{\mathrm{NOB}}$ was the most affected one by the operational temperature decrease with an estimated descent rate of $6 \mathrm{mg} \mathrm{N} /\left(\mathrm{g} \mathrm{VSS} \cdot \mathrm{d} \cdot{ }^{\circ} \mathrm{C}\right)$, which doubled that of the $\mathrm{SA}_{\mathrm{AOB}}$ value (Figure 3.B). This observation contradicts the results from other studies reporting that NOB suppression is even more challenging at low temperature (Cao et al., 2017). The NOB are supposed to be less temperature sensitive than AOB and anammox (due to their lower activation energy) (Trojanowicz et al., 2016). However, in the present study, the decrease in the $\mathrm{SA}_{\mathrm{NOB}}$ cannot be attributed only to the temperature descent, since the biomass used for the assays was collected at different operational days and the microbial population distribution might evolve due to the different SRT and lower biomass growth rates due to the diminishing of temperature.

Considering the separated concentrations of the suspended and biofilm biomass fractions and the corresponding measured specific activities, the maximum achievable conversion capacities (as $\mathrm{g} \mathrm{N} /\left(\mathrm{m}^{3} \cdot \mathrm{d}\right)$ ) of each microbial population were calculated (Figure 4 ). As the fraction of biomass attached to the carrier surface is much higher than the suspended sludge one, the biofilm is the main contributor to the TN removal capacity. Considering the whole biomass fractions inside the system, the total AOB capacity was $1.8-2.0$ times the anammox capacity (Figure 4.B), which is the desirable situation to reach high NRE. Additionally, the ratio of $\mathrm{AOB} / \mathrm{NOB}$ considering both biomass fractions progressively increased from 0.7 in S-I $\left(21^{\circ} \mathrm{C}\right)$ to 1.1 in S-III indicating the promotion of the AOB while the NOB capacity decreased a $53 \%$ (Figure 4). Indeed, at $15^{\circ} \mathrm{C}$ the AOB was the population with the highest total capacity with average values of $167 \mathrm{~g} \mathrm{~N} /\left(\mathrm{m}^{3} \cdot \mathrm{d}\right)$ while the NOB one was of $145 \mathrm{~g} \mathrm{~N} /\left(\mathrm{m}^{3} \cdot \mathrm{d}\right)$. The limitation of NOB activity was also observed during the reactor operation since the measured NOB activity amounted to $10-20 \%$ of the maximum potential capacity obtained from the batch tests. The much lower heterotrophic denitrification capacity, compared with the anammox one (ratios lower than 0.05 in Stages II and III, Figure 4.B), corroborated that the main route of nitrogen removal 
in the IFAS system was the autotrophic pathway. Moreover, a much lower contribution of the heterotrophic denitrification capacity in NRE is expected as the reactor is not completely anoxic and COD supplied was limited (Table 2).

A)

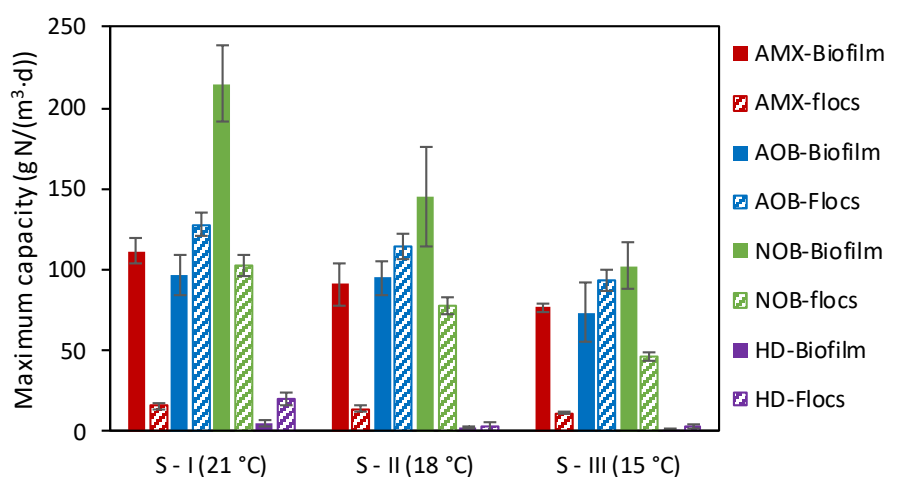

B)

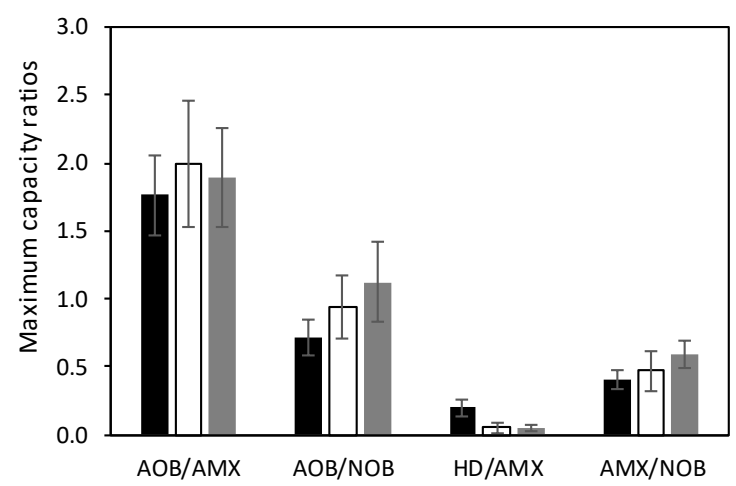

Figure 4. A) Maximum conversion capacity, measured in batch experiments, for the different bacterial populations present in suspended sludge (flocs) and biofilm biomass: anammox (AMX), ammonium oxidizing bacteria ( $\mathrm{AOB}$ ), nitrite oxidizing bacteria (NOB) and heterotrophic denitrifying (HD). B) Evolution of the maximum conversion capacity ratios of the different bacterial populations at decreasing temperatures $21^{\circ} \mathrm{C}(\mathbf{\square}), 18^{\circ} \mathrm{C}(\square)$ and $15^{\circ} \mathrm{C}(\square)$.

The microbial population segregation suggested by the different specific microbial activities (Figure 3 and 4) detected in each biomass fraction was also confirmed by the microbial characterization analysis of a sample collected in Stage II (Table S2 and Figure S2 in Supporting Material). Anammox bacteria represented approximately 33\% of the active bacterial community in the biofilm whereas they only amounted to $12 \%$ of the suspended sludge fraction. Candidatus Brocadia Anammoxidans was the predominant anammox population detected (representing $90 \%$ of the total active anammox). In the case of the suspended sludge fraction, AOB relative abundance was significantly higher $(42.9 \pm 6.1 \%)$ than in the biofilm biomass $(16.9 \pm 4.0 \%)$. NOB were detected in both biofilm and suspended biomass. However, differences among the dominant specie were observed. Nitrospira was the predominant NOB in the suspended sludge at a relative 
abundance of $11.4 \%$ whereas in the case of the biofilm both Nitrospira and Nitrobacter spp. presented similar abundances (Table S2 in Supplementary Material). Nitrospira is the most commonly found specie in reactor systems operated at mainstream conditions as these bacteria present high affinity for substrates being able to survive in nitrite limited environments (Cao et al., 2017). Nitrotoga arctica was also detected in both fractions but in low percentages.

\subsection{Overcoming AOB activity limitation}

Although the obtained AOB/AMX maximum conversion capacity ratio was almost 2 (Figure 4.B), indicating that enough nitrite could be supplied, the ammonium oxidation was identified as one of the main limiting steps during the reactor operation.

AOB activity in the biofilm might be restricted by DO transfer limitation and even if it was high in the flocculent sludge the contribution of this fraction to the global capacity could be insufficient to oxidize enough ammonium to nitrite for the anammox process. Moreover, the length of the aeration phase of 15 or $20 \mathrm{~min}$ might be also too short to reach this required ammonium oxidation but increasing the length of the aerated phase might also promote the development of NOB activity, which was not desired. Only during Stage III, the observed accumulation of low nitrite concentrations (Table 2) indicates that AOB was not limiting the conversion capacity anymore. This fact is explained by both the AOB growth and the NOB suppression, meaning that more nitrite is available for the anammox bacteria.

Another possible action would be the optimization of the previous UASB reactor performance to decrease the COD concentration of the influent to the IFAS system restricting the aerobic heterotrophic bacteria competition with AOB by oxygen.

In addition, in the case of PN/AMX IFAS systems, AOB grow mainly as suspended biomass. In the present study, the $\mathrm{SA}_{\mathrm{AOB}}$ in this biomass fraction was 4 times higher than that of the biofilm (Figure 3.B). Therefore, if suspended biomass concentration augments the ammonium oxidation capacity of the system would increase too, improving the nitrogen removal of the system. However, to increase this biomass concentration was difficult, since it presented poor settling properties and tended to float in the sedimentation tank probably due to the accumulated nitrogen gas produced, which was not appropriately released. 


\subsection{Biomass segregation and NOB suppression in the PN/AMX processes}

To improve the PN/AMX processes stability and effluent quality to suppress the NOB activity, without affecting the anammox bacteria is a requisite. Thus, the IFAS systems arose as a promising alternative for implementing the PN/AMX processes in a one-stage unit since nitrifying bacteria grow mainly in the suspended sludge while anammox bacteria were found in the biofilm (Han et al., 2016; Veuillet et al., 2014).

In the present study, the complete suppression of NOB activity was difficult, since NOB were also well integrated into the biofilm (Figures 3, 4 and Table S2 in Supporting Material). As NOB are aerobic, they should be in the outer layers of the biofilm. Therefore, they might be washed-out by increasing the shear stress imposed in the system to improve the detachment of the loose parts of the biofilm surface and adjusting then the SRT of the flocculent biomass. Although SRT was not controlled in the present study, the NOB capacity diminished in approximately the $50 \%$ for both suspended sludge and biofilm from Stage I to Stage III (Figure 4).

As an additional consideration, it was generally accepted that AOB have oxygen affinities higher than NOB and thus PN/AMX reactors should be operated at low DO concentration (Lackner et al., 2014). However, at low temperatures NOB have oxygen affinities higher than AOB and the use of a strategy based on just the DO concentration control was not suitable for NOB suppression (Regmi et al., 2014; Val del Rio et al., 2019). Although intermittent aeration was widely applied to create transient anoxic conditions, which help the NOB out-selection (Regmi et al., 2014), the induced lag phase failed to completely suppress the NOB activity at low temperature (Agrawal et al., 2018; Cao et al., 2017). In the present study, the NOB activity inside the reactor was limited to $20 \%$ of the SANOB. In this sense, Malovanyy et al. (2015) evaluated the effect of different ratios between the lengths of aerated and non-aerated phases to suppress the NOB activity. The best PN/AMX processes performance achieved in their system (at $25^{\circ} \mathrm{C}$ ) was with an intermittent aeration pattern of $15 \mathrm{~min} \mathrm{ON}$ and $45 \mathrm{~min} \mathrm{OFF}$, a DO set point of $1 \mathrm{mg} \mathrm{O} / \mathrm{L}$ and a sCOD/N ratio equal to $1.8 \mathrm{~g} / \mathrm{g}$, achieving a NRR of $55 \mathrm{~g} \mathrm{~N} /\left(\mathrm{m}^{3} \cdot \mathrm{d}\right)$ with a NRE of $70 \%$. However, the effectiveness of the intermittent aeration strategy also depends on the reactor type and operational conditions. For example, in the present study it was demonstrated that at lower temperatures $\left(18\right.$ and $\left.15^{\circ} \mathrm{C}\right)$ the aeration pattern of $20 \mathrm{~min}$ $\mathrm{ON}$ and $40 \mathrm{~min}$ OFF was more appropriate. 
Other strategies for NOB suppression have been proposed like the operation of the system at high free ammonium (FA) concentrations that lead to a good NOB suppression since the AOB have no substrate limitation and NOB are inhibited at lower FA concentrations than AOB (Blackburne et al., 2007; Vadivelu et al., 2007). The use of free nitrous acid (FNA) to inhibit NOB as it is substantially more harmful for NOB than for AOB was also proposed (Blackburne et al., 2007; Vadivelu et al., 2007). However, with the $\mathrm{pH}$ value of the reactor media (ranging from 6.64 to 7.52 ) neither FA $\left(0.1 \mathrm{mg} \mathrm{NH}_{3}-\mathrm{N} / \mathrm{L}\right)$ nor FNA (0.02 mg $\mathrm{HNO}_{2}-\mathrm{N} / \mathrm{L}$ ) inhibitory concentrations were achieved. Average values were of $0.03 \pm 0.02 \mathrm{mg} \mathrm{NH}-\mathrm{N} / \mathrm{L}$ and $0.10 \pm 0.08 \mu \mathrm{g} \mathrm{HNO}_{2}-\mathrm{N} / \mathrm{L}$, respectively. Inhibitory FA concentrations would be only possible if large ammonium concentrations were present inside the reactor diminishing the NRE. To obtain inhibitory FNA concentrations in a one-stage system would be difficult as anammox bacteria consume nitrite and they are more sensitive to this compound than NOB. This problem might be avoided if the reactor was a SBR or a plug flow reactor where gradient concentrations are easily achieved.

To maintain the stable PN/AMX processes stability at low temperature is especially difficult due to the unbalance of the AOB and anammox bacteria activities as well as the challenging effective suppression of NOB. For these reasons, in IFAS systems to be competitive with the conventional biological nitrogen removal systems, the maintaining of the AOB activity at long-term operation while NOB one is suppressed needs to be further addressed as well as the maximum NRR achievable.

In addition, to operate the PN/AMX processes stable at mainstream conditions they need to cope with the high wastewater fluctuations in terms of temperature, flow rates and composition. Thus, the definition of a robust and good control strategy would help to face this challenge. Besides, this is one of the main fields of research which lack of information as the long-term stable PN/AMX studies, at mainstream conditions, were performed mostly at laboratory scale (Cao et al. 2017).

\section{Conclusions}

The feasibility of operating a one-stage mainstream PN/AMX processes in an IFAS reactor configuration was proved at pilot scale. Anaerobically pre-treated municipal wastewater was treated at decreasing temperatures $\left(21-15^{\circ} \mathrm{C}\right)$ achieving an average NRE of $72 \pm 11 \%$. At $15^{\circ} \mathrm{C}$, the process stability was maintained reaching average NRR of 37 $\pm 3 \mathrm{~g} \mathrm{~N} /\left(\mathrm{m}^{3} \cdot \mathrm{d}\right)$, comparable with that observed in conventional nutrient removal systems 
operated at mainstream conditions. During the IFAS operation NOB were present but their activity was successfully suppressed observing less than the $20 \%$ and $10 \%$ of the maximum potential $\mathrm{NOB}$ activity inside the reactor at 21 and $15{ }^{\circ} \mathrm{C}$, respectively. Microbial population segregation was observed being the AOB and NOB more abundant in the flocculent fraction while the biofilm was mostly composed by the anammox bacteria. This fact could facilitate the selection of those populations mainly present as biofilm and the selective wash out of the flocculent biomass helping to suppress the NOB activity.

\section{Declarations of interest: none}

\section{Acknowledgments}

This work was done within the Pioneer_STP (ID 199 (UE)/PCIN-2015-022 (AEI)/FR2016/0002(Formas)) project funded by the WaterWorks2014 Cofunded Call (Water JPI/Horizon 2020). A. Pedrouso also want to thank the support by a STSM Grant from COST Action Water_2020 (COST-STSM-ES1202-010216-076068) for her research stay at KTH in Sweden. The authors from the USC belong to CRETUS Strategic Partnership (ED418B 2017/075) and to the Galician Competitive Research Group (GRC-ED431C 2017/29). All these programs are cofunded by FEDER (UE) funds. The authors from KTH belong to VA Mälardalen Cluster funded by Swedish Water Development (SVU). The authors would like to acknowledge the staff at Hammarby Sjöstadsverk, Stockholm (Swedish Water Innovation Center) and the Swedish Environmental Research Institute (IVL) for their support.

\section{References}

Agrawal, S., Seuntjens, D., Cocker, P.D., Lackner, S., Vlaeminck, S.E., 2018. Success of mainstream partial nitritation/anammox demands integration of engineering, microbiome and modeling insights. Curr. Opin. Biotech. 50, 214-221. doi: 10.1016/j.copbio.2018.01.013.

Amann, R.I., Krumholz, L., Stahl, D.A., 1990. Fluorescent-oligonucleotide probing of whole cells for determinative, phylogenetic, and environmental studies in microbiology. J. Bacteriol. 172, 762-770. doi: 10.1128/jb.172.2.762-770.1990.

American Public Health Association, American Water Works Association, Water Environment Federation, 2017. Standard methods for the examination of water and wastewater, 23rd edition. ed. American Public Health Association, Washington, DC. 
Blackburne, R., Vadivelu, V.M., Yuan, Z., Keller, J., 2007. Kinetic characterisation of an enriched Nitrospira culture with comparison to Nitrobacter. Water Res. 41, 3033-3042. doi: 10.1016/j.watres.2007.01.043.

Burton, F.L., Tchobanoglous, G., Tsuchihashi, R., Stensel, H.D., Metcalf \& Eddy, I., 2014. Wastewater engineering : treatment and resource recovery. McGraw-Hill Education.

Cao, Y., van Loosdrecht, M.C., Daigger, G.T., 2017. Mainstream partial nitritationanammox in municipal wastewater treatment: status, bottlenecks, and further studies. Appl. Microbiol. Biotechnol. 101, 1365-1383. doi: 10.1007/s00253-016-8058-7.

Daims, H., Lücker, S., Wagner, M., 2006. Daime, a novel image analysis program for microbial ecology and biofilm research. Environ. Microbiol. 8, 200-213. doi: 10.1111/j.1462-2920.2005.00880.x.

Dapena-Mora, A., Fernández, I., Campos, J.L., Mosquera-Corral, A., Méndez, R., Jetten, M.S.M., 2007. Evaluation of activity and inhibition effects on Anammox process by batch tests based on the nitrogen gas production. Enzyme and Microb. Technol. 40, 859-865. doi: 10.1016/j.enzmictec.2006.06.018.

Dosta, J., Vila, J., Sancho, I., Basset, N., Grifoll, M., Mata-Álvarez, J., 2015. Two-step partial nitritation/Anammox process in granulation reactors: Start-up operation and microbial characterization. J. Environ. Manag. 164, 196-205. doi: 10.1016/j.jenvman.2015.08.023.

Ge, S., Wang, S., Yang, X., Qiu, S., Li, B., Peng, Y., 2015. Detection of nitrifiers and evaluation of partial nitrification for wastewater treatment: A review. Chemosphere 140, 85-98. doi: 10.1016/j.chemosphere.2015.02.004.

Greuter, D., Loy, A., Horn, M., Rattei, T., 2016. probeBase-an online resource for rRNA-targeted oligonucleotide probes and primers: new features 2016. Nucleic Acids Research 44, D586-D589. doi: 10.1093/nar/gkv1232.

Han, M., Vlaeminck, S.E., Al-Omari, A., Wett, B., Bott, C., Murthy, S., De Clippeleir, H., 2016. Uncoupling the solids retention times of flocs and granules in mainstream deammonification: A screen as effective out-selection tool for nitrite oxidizing bacteria. Bioresour. Technol. 221, 195-204. doi: 10.1016/j.biortech.2016.08.115.

Hoekstra, M., Geilvoet, S.P., Hendrickx, T.L.G., van Erp Taalman Kip, C.S., Kleerebezem, R., van Loosdrecht, M.C.M., 2018. Towards mainstream anammox: lessons learned from pilot-scale research at WWTP Dokhaven. Environ Technol, 1-13. doi: 10.1080/09593330.2018.1470204. 
Lackner, S., Gilbert, E.M., Vlaeminck, S.E., Joss, A., Horn, H., van Loosdrecht, M.C.M., 2014. Full-scale partial nitritation/anammox experiences - An application survey. Water Res. 55, 292-303. doi: 10.1016/j.watres.2014.02.032.

Laureni, M., Falås, P., Robin, O., Wick, A., Weissbrodt, D.G., Nielsen, J.L., Ternes, T.A., Morgenroth, E., Joss, A., 2016. Mainstream partial nitritation and anammox: long-term process stability and effluent quality at low temperatures. Water Res. 101, 628-639. doi: 10.1016/j.watres.2016.05.005.

Lotti, T., Kleerebezem, R., Hu, Z., Kartal, B., de Kreuk, M.K., van Erp Taalman Kip, C., Kruit, J., Hendrickx, T.L.G., van Loosdrecht, M.C.M., 2015. Pilot-scale evaluation of anammox-based mainstream nitrogen removal from municipal wastewater. Environ. Technol. 36, 1167-1177. doi: 10.1080/09593330.2014.982722.

Malovanyy, A., Trela, J., Plaza, E., 2015. Mainstream wastewater treatment in integrated fixed film activated sludge (IFAS) reactor by partial nitritation/anammox process. Bioresour. Technol. 198, 478-487. doi: 10.1016/j.biortech.2015.08.123.

Pedrouso, A., Aiartza, I., Morales, N., Vázquez-Padín, J.R., Rogalla, F., Campos, J.L., Mosquera-Corral, A., Val del Rio, A., 2018. Pilot-scale ELAN® process applied to treat primary settled urban wastewater at low temperature via partial nitritation-anammox processes. Sep. Purif. Technol. 200, 94-101. doi: 10.1016/j.seppur.2018.02.017.

Pérez, J., Isanta, E., Carrera, J., 2015. Would a two-stage N-removal be a suitable technology to implement at full scale the use of anammox for sewage treatment? Water Sci. Technol. 72, 858-864. doi: 10.2166/wst.2015.281.

Regmi, P., Miller, M.W., Holgate, B., Bunce, R., Park, H., Chandran, K., Wett, B., Murthy, S., Bott, C.B., 2014. Control of aeration, aerobic SRT and COD input for mainstream nitritation/denitritation. Water Res. 57, 162-171. doi: 10.1016/j.watres.2014.03.035.

Regmi, P., Thomas, W., Schafran, G., Bott, C., Rutherford, B., Waltrip, D., 2011. Nitrogen removal assessment through nitrification rates and media biofilm accumulation in an IFAS process demonstration study. Water Res. 45, 6699-6708. doi: 10.1016/j.watres.2011.10.009.

Surmacz-Gorska, J., Gernaey, K., Demuynck, C., Vanrolleghem, P., Verstraete, W., 1996. Nitrification monitoring in activated sludge by oxygen uptake rate (OUR) measurements. Water Res. 30, 1228-1236. doi: 10.1016/0043-1354(95)00280-4. 
Trojanowicz, K., Plaza, E., Trela, J., 2016. Pilot scale studies on nitritation-anammox process for mainstream wastewater at low temperature. Water Sci. Technol. 73, 761-768. doi: 10.2166/wst.2015.551.

Vadivelu, V.M., Keller, J., Yuan, Z., 2007. Free ammonia and free nitrous acid inhibition on the anabolic and catabolic processes of Nitrosomonas and Nitrobacter, Water Sci. Technol. 89-97.

Val del Rio, A., Campos, J.L., Da Silva, C., Pedrouso, A., Mosquera-Corral, A., 2019. Determination of the intrinsic kinetic parameters of ammonia-oxidizing and nitriteoxidizing bacteria in granular and flocculent sludge. Sep. Purif. Technol. 213, 571-577. doi: 10.1016/j.seppur.2018.12.048.

Veuillet, F., Lacroix, S., Bausseron, A., Gonidec, E., Ochoa, J., Christensson, M., Lemaire, R., 2014. Integrated fixed-film activated sludge ANITA ${ }^{\text {TMMox }}$ process - A new perspective for advanced nitrogen removal. Water Sci. Technol. 69, 915-922. doi: 10.2166/wst.2013.786.

Yang, Y., Zhang, L., Cheng, J., Zhang, S., Li, B., Peng, Y., 2017. Achieve efficient nitrogen removal from real sewage in a plug-flow integrated fixed-film activated sludge (IFAS) reactor via partial nitritation/anammox pathway. Bioresour. Technol. 239, 294301. 10.1016/j.biortech.2017.05.041. 